\title{
Pengaruh Kredibilitas Deddy Corbuzier sebagai Brand Ambassador J\&T terhadap Citra Merek J\&T
}

\author{
Jansen Tiawan', Moehammad Gafar Yoedtadi* \\ ${ }^{1}$ Fakultas Ilmu Komunikasi Universitas Tarumanagara \\ Email: jansen915170095@stu.untar.ac.id \\ ${ }^{2}$ Fakultas Ilmu Komunikasi Universitas Tarumanagara* \\ Email: gafary@fikom.untar.ac.id
}

Masuk tanggal : 15-12-2021, revisi tanggal : 06-01-2022, diterima untuk diterbitkan tanggal : 16-01-2022

\begin{abstract}
The increasing use of brand ambassadors as a branding activity has resulted in many companies participating in this strategy. Selection of brands quality ambassadors can influence the brand image of a product. Credibility of a good and trusted brand ambassador can generate public trust, thereby enhancing the brand image. In this study, Deddy Corbuzier is a brand ambassador owned by PT J\&T. The purpose of this study was to determine the influence of the credibility that Deddy Corbuzier has as the brand ambassador of PT J\&T through instagam on the brand image of PT $J \& T$. This research is a quantitative research with a survey method. The population in this study were all Instagram account users who followed the $J \& T$ account. While the authors took a sample of 100 respondents. Sampling was done using non probability sampling techniques. Data processing and analysis techniques are based on simple regression analysis, without coefficient, coefficient determination, T test. Data validation techniques are based on validity testing, reliability testing. and normality test. Based on the research results, it is known that there is a positive influence between the credibility of brand ambassadors and brand image. The credibility of brand ambassadors has an effect of $58.4 \%$ on brand image. If the credibility of brand ambassadors increases, the brand image will also increase. In fact, if the credibility of a brand ambassador decreases, the brand image will also decline.
\end{abstract}

Keywords: brand ambassador, brand image, credibility

\begin{abstract}
Abstrak
Maraknya penggunaan brand ambassador mendorong banyak perusahaan menggunakan strategi ini sebagai salah satu kegiatan branding. Pemilihan brand ambassador yang berkualitas dapat mempengaruhi citra merek dari suatu produk atau jasa. Kredibilitas brand ambassador yang baik dan terpecaya dapat menimbulkan kepercayaan public sehingga meningkatkan citra merek. Dalam penelitian ini, Deddy Corbuzier merupakan brand ambassador yang dimiliki oleh PT J\&T.Penelitian ini bertujuan untuk mengetahui pengaruh kredibilitas yang dimiliki oleh Deddy Corbuzier sebagai brand ambassador PT $J \& T$ melalui instagam terhadap citra merek PT J\&T. Penelitian ini menggunakan pedekatan kuantitatif dengan metode survey. Populasi dalam penelitian ini adalah seluruh pengguna akun instagram yang mengikuti akun J\&T. Sedangkan penulis mengambil sampel sebanyak 100 responden. Pengambilan sampel dilakukan dengan menggunakan teknik non probability sampling. Teknik pengolahan dan analisis data berdasarkan analisis regresi linear sederhana, koefisien korelasi, koefisien determinasi, uji T. Teknik pengabsahan data berdasarkan uji validitas, uji realibilitas. dan uji normalitas. Berdasarkan hasil penelitian, diketahui bahwa terdapat pengaruh positif antara kredibilitas brand ambassador terhadap citra merek. Kredibilitas brand ambassador memiliki pengaruh sebesar 58,4\% terhadap citra merek. Apabila kredibilitas brand ambassador meningkat maka citra merek juga akan
\end{abstract}


semakin meningkat. Sebaliknya, jika kredibilitas brand ambassador menurun maka citra merek juga akan semakin menurun.

Kata Kunci: brand ambassador, citra merek, kredibilitas

\section{Pendahuluan}

Berkomunikasi adalah cara paling efektif untuk menyampaikan pesan kepada khalayak. Dengan komunikasi, manusia dapat mencapai tujuan mereka. Menurut Suranto (2011) manusia berkomunikasi antar satu dengan yang lainnya dengan langsung untuk menghindari resiko salah paham dalam penyampaian pesan.

Menurut Mulyana (2014) terdapat beberapa aspek dalam sebuah model komunikasi. Terdapat komunikator yang menyaring dan memberi pesan melalui suatu saluran dan mendapat gangguan kepada komunikan yang turut menyaring pesan dan memberikan umpan balik. Meski komunikasi secara sederhana dapat dibatasi melalui dua orang, komunikasi juga dapat terjadi melalui proses komunikasi lainnya. Salah satunya ialah komunikasi massa. Komunikasi massa dapat dilakukan melalui media cetak atau elektronik, yang menyampaikan suatu pesan yang ditujukan untuk sebagian besar kelompok.

Salah satu bentuk komunikasi massa yang paling banyak digunakan adalah media sosial. Utami dan Triyono (2011) menjelaskan bahwa media sosial merupakan media berbasis daring yang diciptakan untuk mempermudah pengguna dalam berbagi dan berpartisipasi dalam berbagai jejaring sosial, forum, maupun dunia maya.

Media sosial yang kian marak digunakan adalah Instagram. Menurut Nisrina (2015) Instagram merupakan suatu aplikasi yang digunakan untuk menyebarluaskan foto dan video oleh pengguna kepada publiknya. Salah satu cara yang banyak dimanfaatkan pemilik bisnis dalam mempromosikan usaha dan membangun citra merek mereka melalui instagram adalah melalui brand ambassador. Brand ambassador diterapkan sebagai salah satu strategi untuk meningkatkan minat serta membangun citra suatu perusahaan, produk, atau merek. Menurut Terence (2010) brand ambassador merupakan seseorang yang menjadi pendukung iklan atau disebut juga sebagai bintang iklan yang mendukung produk atau jasa yang diiklankan.

Sigar, Londa, dan Tulung (2016) menjelaskan bahwa kredibilitas komunikator bersumber pada:

a) Keahlian (expertise), yaitu kemampuan seorang komunikator untuk membuat dan menjual produk kepada konsumen.

b) Kepercayaan (trustworthiness), yaitu sejauh mana komunikator tampak termotivasi untuk menjadi jujur, bergantung dan peka terhadap kebutuhan konsumen.

c) Daya tarik (attractiveness), yaitu konsep diri yang dimiliki oleh seseorang atau merupakan suatu identifikasi diri yang memperjelas konsep diri seseorang tersebut.

Kehadiran brand ambassador diterapkan sebagai salah satu strategi untuk meningkatkan minat dan membentuk citra suatu perusahaan atau merek. Menurut Supriyanto dan Ernawaty (2010) brand image adalah persepsi terhadap sebuah merek yang berhubungan dengan sikap (attitude) pasar yang meliputi tingkat kesukaan dan manfaat yang dipersepsikan bila nanti digunakan. Mudiantono (2016) mengatakan bahwa umumnya tokoh public figure khusunya selebritas dipercaya dapat mempengaruhi sikap dan membangun keyakinan serta kepercayaan konsumen akan produk atau jasa yang dipromosikan. 
Menurut Aaker (Setyanto, 2017) dikatakan bahwa brand image merupakan kumpulan asosiasi yang tersusun dengan tujuan tertentu. Brand image mengacu pada ingatan skematik dari suatu merek yang memuat interpretasi target pasar dari atribut produk, manfaat situasi penggunaan, pengguna, manufaktur atau karakteristik pemasar.

Berdasarkan penjelasan tersebut dapat disimpulkan bahwa brand ambassador merupakan suatu ikon atau identitas yang bertindak sebagai suatu alat pemasaran dari suatu perusahaan, produk, atau jasa untuk mencapai tujuan perusahaan yaitu menciptakan dan meningkatkan brand image serta penjualan. Pada penelitian ini penulis berupaya mengetahui pengaruh kredibilitas Deddy Corbuzier selaku brand ambassador melalui media sosial instagram terhadap citra merek J\&T. Guna memenuhi tujuan penelitian tersebut, maka penulis menggunakan metode penelitian yang disesuaikan dengan masalah dalam penelitan ini.

\section{Metode Penelitian}

Penelitian ini menggunakan pendekatan kuantitatif. Siyoto dan Sodik (2015) menjelaskan penelitian dengan pendekatan kuantitatif merupakan salah satu jenis penelitian yang sistematis, terencana, dan terstruktur dengan jelas dari awal pembuatan desain penelitiannya menggunakan penggunaan angka, gambar, tabel, grafik, dan tampilan lainnya. Penelitian kuantitatif dilakukan dengan proses pembatasan terhadap variabel-variabel yang menjadi fokus penelitian dan hanya mengumpulkan data yang diperlukan untuk menjawab research questions dan membuktikan hipotesis yang telah disusun.

Penelitian ini dilakukan dengan menggunakan metode survey untuk menemukan kejadian relatif, hubungan antar variabel, dan sosiologis. Penelitian survey menurut Rohman (2012) merupakan suatu penelitian yang menggunakan daftar pernyataan yang terstruktur kepada banyak orang untuk diperoleh dan disusun hasilnya di kemudian hari, lalu diolah dan dianalisis. Metode survey dalam penelitian ini digunakan untuk mendapatkan hasil penelitian dan menjawab permasalahan penelitian terkait pengaruh dari karakter dan kredibilitas yang dimiliki oleh Dedy Corbuzier sebagai brand ambassador J\&T terhadap citra merek. Penarikan sampel menggunakan teknik nonprobability, yaitu penarikan yang tidak memberikan peluang yang sama bagi seluruh anggota populasi untuk dijadikan sebagai sampel penelitian. Dalam penelitian ini, peneliti memakai teknik nonprobability sampling dengan pendekatan purposive sampling. Penelitian ini diukur dengan skala likert menggunakan bantuan software SPSS ver. 15 untuk menguji validitas, reabilitas, dan hipotesis

\section{Hasil Temuan dan Diskusi}

Dalam penelitian ini, peneliti menyebarkan kuesioner kepada 75 responden untuk mendapatkan data berupa jenis kelamin. Sebanyak 58,7\% responden dengan jenis kelamin laki-laki dan sebanyak $41,3 \%$ dengan jelas kelamin perempuan. Sedangkan pada usia, di dominasi pada umur 21 - 30 tahun dengan persentase $68,0 \%$, kemudian $18-20$ tahun dengan persentase $26,7 \%$, dan kemudian $24-26$ tahun sebanyak 5,3\%.

Setelah melakukan uji validitas dengan menggunakan aplikasi SPSS for windows versi 25 , maka berikut adalah hasil dari uji validitas. 
Tabel 1. Uji Validitas

\begin{tabular}{clcc}
\hline \multirow{2}{*}{ Variabel } & Butir Indikator & $\begin{array}{c}\text { Corrected } \\
\text { Item Total } \\
\text { Correlation }\end{array}$ & Keterangan \\
\hline \multirow{4}{*}{$\begin{array}{c}\text { Kredibilitas Brand } \\
\text { Ambassador } \\
\text { (X) }\end{array}$} & KBA 1 & 0,765 & Valid \\
\cline { 2 - 4 } & KBA2 & 0,722 & Valid \\
\cline { 2 - 4 } & KBA3 & 0,735 & Valid \\
\cline { 2 - 4 } & KBA4 & 0,499 & Valid \\
\cline { 2 - 4 } & KBA5 & 0,691 & Valid \\
\cline { 2 - 4 } Citra Merek & KBA6 & 0,627 & Valid \\
\cline { 2 - 4 } & KBA7 & 0,591 & Valid \\
\cline { 2 - 4 } & CM1 & 0,677 & Valid \\
\cline { 2 - 4 } & CM3 & 0,711 & Valid \\
\cline { 2 - 4 } & CM4 & 0,734 & Valid \\
\cline { 2 - 4 } & CM5 & 0,690 & Valid \\
\cline { 2 - 4 } & CM6 & 0,666 & Valid \\
\cline { 2 - 4 } & CM7 & 0,749 & Valid \\
\cline { 2 - 4 } & CM8 & 0,689 & Valid \\
\hline
\end{tabular}

Sumber: Hasil Pengolahan Data SPSS Ver 25

Tabel 1, menunjukkan bahwa butir-butir indikator pernyataan dari seluruh variabel dinyatakan valid seluruhnya karena memiliki angka korelasi di atas 0,2.

Tabel 2. Uji Reliabilitas

\begin{tabular}{ccc}
\hline Variabel & Nilai Cronbach's Alpha & Keterangan \\
\hline $\begin{array}{c}\text { Kredibilitas Brand } \\
\text { Ambassador }(\mathrm{X})\end{array}$ & 0,879 & Reliabel \\
\hline Citra Merek (Y) & 0,901 & Reliabel \\
\hline
\end{tabular}

Sumber: Hasil Pengolahan Data SPSS Ver 25

Tabel 2, menunjukkan bahwa setiap pernyataan dalam kuisoner dikatakan reliabel karena memiliki nilai Cronbach's Alpha di atas 0,6.

Tabel 3. Uji Normalitas

One-Sample Kolmogorov-Smirnov Test

\begin{tabular}{llr} 
N & & 75 \\
Normal Parameters ${ }^{\mathrm{a}, \mathrm{b}}$ & Mean & .0000000 \\
& Std. Deviation & 3.60092194 \\
Most Extreme & Absolute & .114 \\
Differences & Positive & .114 \\
& Negative & -.103 \\
Test Statistic & & .114 \\
Asymp. Sig. (2-tailed) & & $.018^{\mathrm{c}}$ \\
Monte Carlo Sig. (2- & Sig. & $.272^{\mathrm{d}}$ \\
\hline
\end{tabular}




\begin{tabular}{llll}
\hline tailed) & $\begin{array}{l}99 \% \text { Confidence } \\
\text { Interval }\end{array}$ & $\begin{array}{l}\text { Lower } \\
\text { Bound } \\
\text { Upper Bound }\end{array}$ & .260 \\
& & .283 \\
\hline
\end{tabular}

Sumber: Hasil Pengolahan Data SPSS Ver 25

Dalam penelitian ini, peneliti menggunakan uji One Sample Kolmogorov Smirnov yang ada pada aplikasi SPSS Ver 25. Hasil analisis pada tabel 3 menunjukan bahwa ada nilai signifikansi sebesar 0,272 untuk residual. Hasil tersebut menyatakan bahwa distribusi data berdistribusi secara normal karena nilai signifikansi $>0,05$.

Tabel 4. Hasil Uji T

\begin{tabular}{ccccccc}
\hline \multirow{2}{*}{ Model } & \multicolumn{2}{c}{$\begin{array}{c}\text { Unstandardized } \\
\text { Coefficients }\end{array}$} & $\begin{array}{c}\text { Standardized } \\
\text { Coefficients }\end{array}$ & T & Sig. \\
\hline 1 & (Constant) & $\mathrm{B}$ & $\begin{array}{c}\text { Std. } \\
\text { Error }\end{array}$ & Beta & & \\
\cline { 2 - 7 } & & & & 1,671 & 0,099 \\
\hline \multirow{2}{*}{$\begin{array}{c}\text { Kredibilitas } \\
\text { Brand } \\
\text { Ambassador }\end{array}$} & 0,430 & 2,651 & & 0,764 & 10,115 & 0,000 \\
\cline { 2 - 7 } & & 0,095 & 0,767 & & & \\
\hline
\end{tabular}

Sumber: Hasil Pengolahan Data SPSS Ver 25

Tabel 4 menunjukkan dari hasil analisis data diketahui bahwa nilai $\mathrm{t}=10,115$ dan tingkat signifikansi $=0,00<0,05$. Karena nilai p lebih kecil dari 0,05 , maka $\mathrm{H}_{0}$ ditolak dan $\mathrm{H}_{\mathrm{a}}$ diterima, yang dapat disimpulkan terdapat pengaruh yang signifikan antara kredibilitas brand ambassador terhadap citra merek.

Tabel 5. Hasil Uji Regresi Linear Sederhana

\begin{tabular}{|c|c|c|c|c|c|c|}
\hline & Model & $\begin{array}{r}\text { Unstan } \\
\text { Coeff }\end{array}$ & $\begin{array}{l}\text { rdized } \\
\text { ients }\end{array}$ & $\begin{array}{c}\text { Standardized } \\
\text { Coefficients }\end{array}$ & $\mathrm{T}$ & Sig. \\
\hline 1 & (Constant) & B & $\begin{array}{l}\text { Std. } \\
\text { Error }\end{array}$ & Beta & & \\
\hline & Kredibilitas & 4,430 & 2,651 & & 1,671 & 0,099 \\
\hline & $\begin{array}{c}\text { Brand } \\
\text { Ambassado }\end{array}$ & 0,957 & 0,095 & 0,764 & 10,115 & 0,000 \\
\hline
\end{tabular}

Sumber: Hasil Pengolahan Data SPSS Ver 25

Dengan keterangan $\mathrm{Y}=$ Citra Merek dan $\mathrm{X}=$ Kredibilitas Brand Ambassador. Berdasarkan persamaan regresi linear pada tabel 5, dapat dijabarkan sebagai berikut:

1. Nilai Y (Citra Merek) akan tetap sebesar 4,430 konstanta jika nilai X (Kredibilitas Brand Ambassador) tidak mengalami perubahan, baik peningkatan maupun penurunan.

2. Jika nilai $X$ (Kredibilitas Brand Ambassador) mengalami peningkatan nilai sebesar 1 satuan, maka nilai Y (Citra Merek) akan mengalami peningkatan sebesar 0,957 menjadi 5,387. 
Tabel 6. Hasil Uji Koefisien Korelasi

\begin{tabular}{ccccc}
\hline Model & $\mathrm{R}$ & $\mathrm{R}$ Square & $\begin{array}{c}\text { Adjusted R } \\
\text { Square }\end{array}$ & $\begin{array}{c}\text { Std. Error of } \\
\text { the Estimate }\end{array}$ \\
\hline 1 & $.764 \mathrm{a}$ & .584 & .578 & 3,62550 \\
\hline
\end{tabular}

Sumber: Hasil Pengolahan Data SPSS Ver 25

Dari hasil perhitungan tabel 6, didapati bahwa nilai koefisien korelasi $\mathrm{R}$ sebesar 0,764 yang berada di antara interval 0,60-0,799 artinya kredibilitas brand ambassador mempunyai hubungan yang kuat terhadap citra merek.

Tabel 7. Hasil Uji Determinasi

\begin{tabular}{ccccc}
\hline Model & $\mathrm{R}$ & $\mathrm{R}$ Square & $\begin{array}{c}\text { Adjusted R } \\
\text { Square }\end{array}$ & $\begin{array}{c}\text { Std. Error of } \\
\text { the Estimate }\end{array}$ \\
\hline 1 & $.764 \mathrm{a}$ & .584 & .578 & 3,62550 \\
\hline
\end{tabular}

Sumber: Hasil Pengolahan Data SPSS Ver 25

Dari hasil perhitungan tabel 7, didapati nilai pada tabel R Square sebesar 0,584 mengartikan bahwa 58,4\% citra merek dipengaruhi oleh kredibilitas brand ambassador sementara sisanya 41,6\% (100\%-58,4\%) dipengaruhi oleh faktor lain.

\section{Simpulan}

Penelitian ini menyimpulkan bahwa antara kredibilitas brand ambassador dengan citra merek memiliki kesinambungan yang baik. Hasil dari uji koefisien korelasi menghasilkan nilai korelasi yang berada di interval 0,60 - 0,799 yang menunjukkan bahwa kredibilitas brand ambassador memiliki pengaruh yang kuat terhadap citra merek dan bersifat positif. Dengan demikian, semakin meningkatnya kredibilitas brand ambassador maka citra merek juga akan semakin meningkat. Sebaliknya jika kredibiltas brand ambassador menurun maka citra merek juga akan menurun.

Berdasarkan kuesioner yang telah disebarkan, data pernyataan sebanyak 15 butir pernyataan dikatakan valid, karena semuanya pernyataan yang telah disebarkan mendukung bahwa terdapat pengaruh antara kredibilitas brand ambassador terhadap citra merek perusahaan.

\section{Ucapan Terima Kasih}

Peneliti ingin mengucapkan terima kasih kepada Fakultas Ilmu Komunikasi Universitas Tarumanagara, narasumber, serta semua pihak yang turut membantu peneliti sehingga penelitian ini dapat diselesaikan.

\section{Daftar Pustaka}

Mudiantono, S. P. R. (2016). Analisis Pengaruh Brand Ambassador, Kualitas Dampaknya Terhadap Keputusan Pembelian. Diponegoro Journal of Management, 5, 1-12.

Mulyana, Dedy. (2014). Ilmu Komunikasi Suatu Pengantar (ed. 21). Bandung: PT Remaja Rosdakarya. 
Nisrina, M. (2015). Bisnis Online, Manfaat Media Sosial Dalam Meraup Uang. Yogyakarta: Kobis.

Rohman, Ali Syaichu. (2012). Minat Siswa dalam Mata Pelajaran Sejarah Kebudayaan Islam di Kelas VIII H MtsN Ariyojeding Rejotangan Tulungagung Tahun 2011/ 2012. Jurnal Sains dan Teknologi Terapan, 3, 1.

Setyanto, Yugih., Anggarina, Paula., \& Valentina, Anny. (2017). Branding yang dilakukan Humas Pada Perguruan Tinggi Swasta. Jurnal Muara Ilmu Sosial, Humaniora, Seni, 1, 171-182.

Sigar, S, Hendry., Londa, Nolly., Tulung, E, Lingkan. (2017). Persepsi Jemaat Terhadap Kredibilitas Pelayanan Khusus Sebagai Komunikator. Jurnal Acta Diurna, 6, 3.

Siyoto, Sandu., \& Sodik, Ali. (2015). Dasar Metodologi Penelitian. Yogyakarta: Literasi Media Publishing.

Supriyanto., S dan Ernawaty. (2010). Pemasaran Industri Jasa Kesehatan. Yogyakarta: CV Andi Offset.

Suranto, A.W. (2011). Komunikasi Interpersonal. Yogyakarta: Graha Ilmu.

Terence, A. Shimp. (2010), Periklanan Promosi dan Aspek Tambahan Komunikasi Pemasaran Terpadu. Jakarta: Erlangga.

Utami, Agustin Dyah dan Triyono, Ramadian Agus, (2011). Pemanfaatan Blackberry Sebagai Sarana Komunikasi dan Penjualan Batik Online dengan Sistem Dropship di Batik Solo 85. IJNS,2302-5700. 